\title{
Reading the wedding at Cana in Galilee (Jn 2:1-11) through the lenses of introverted sensing and introverted intuition: Perceiving text differently
}

\begin{tabular}{|c|c|}
\hline \multicolumn{2}{|c|}{$\begin{array}{l}\text { Authors: } \\
\text { Leslie J. Francis }{ }^{1,4} \text { (1) } \\
\text { Adam J. Stevenson } \\
\text { Christopher F.J. Ross }{ }^{3,4} \text { (] }\end{array}$} \\
\hline \multicolumn{2}{|c|}{$\begin{array}{l}{ }^{1} \text { CEDAR, Faculty of Social } \\
\text { Sciences, University of } \\
\text { Warwick, Coventry, United } \\
\text { Kingdom }\end{array}$} \\
\hline \multicolumn{2}{|c|}{$\begin{array}{l}{ }^{2} \text { Department of Education } \\
\text { Studies, Faculty of Social } \\
\text { Science, University of } \\
\text { Warwick, Coventry, United } \\
\text { Kingdom }\end{array}$} \\
\hline \multicolumn{2}{|c|}{$\begin{array}{l}{ }^{3} \text { Department of Spiritual Care } \\
\text { and Psychotherapy, Martin } \\
\text { Luther University College, } \\
\text { Waterloo, Ontario, Canada }\end{array}$} \\
\hline \multicolumn{2}{|c|}{$\begin{array}{l}\text { 4Department of New } \\
\text { Testament Studies and } \\
\text { Related Literature, Faculty } \\
\text { Theology and Religion, } \\
\text { University of Pretoria, } \\
\text { Pretoria, South Africa }\end{array}$} \\
\hline \multicolumn{2}{|c|}{$\begin{array}{l}\text { Corresponding author: } \\
\text { Leslie Francis, } \\
\text { leslie.francis@warwick.ac.uk }\end{array}$} \\
\hline \multicolumn{2}{|c|}{$\begin{array}{l}\text { Dates: } \\
\text { Received: } 21 \text { May } 2021 \\
\text { Accepted: } 02 \text { July } 2021 \\
\text { Published: } 25 \text { Aug. } 2021\end{array}$} \\
\hline \multicolumn{2}{|c|}{$\begin{array}{l}\text { How to cite this article: } \\
\text { Francis, L.J., Stevenson, A.J. \& } \\
\text { Ross, C.F.J., 2021, 'Reading } \\
\text { the wedding at Cana in } \\
\text { Galilee (Jn 2:1-11) through } \\
\text { the lenses of introverted } \\
\text { sensing and introverted } \\
\text { intuition: Perceiving text } \\
\text { differently', HTS Teologiese } \\
\text { Studies/Theological Studies } \\
\text { 77(4), a6858. https://doi. } \\
\text { org/10.4102/hts.v77i4.6858 }\end{array}$} \\
\hline \multicolumn{2}{|l|}{ Read online: } \\
\hline 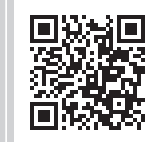 & $\begin{array}{l}\text { Scan this QR } \\
\text { code with your } \\
\text { smart phone or } \\
\text { mobile device } \\
\text { to read online. }\end{array}$ \\
\hline
\end{tabular}

Working within the reader perspective approach to biblical hermeneutics, a series of empirical studies have tested the theory that the readers' psychological type preference between sensing and intuition (the two Jungian perceiving functions) shapes distinctive readings of biblical narratives. More recently, closer attention has also been given to differentiation within these two perceiving functions of sensing and intuition with regard to their introverted and extraverted orientation. Against this background, the present study examines the distinctive reading of the Johannine narrative of the wedding at Cana, a passage rich in materials to engage the perceiving functions, by two groups whose dominant or auxiliary functions were introverted sensing and introverted intuition.

Contribution: Situated within the reader perspective approach to biblical hermeneutics, the sensing, intuition, feeling, thinking (SIFT) method is concerned with identifying the influence of the psychological type of the reader in shaping the interpretation of text. The foundations of the SIFT approach distinguish amongst the four functions of sensing, intuition, feeling and thinking. The present study builds on this foundation by introducing the nuance of the orientation in which the function is expressed, in this case focusing specifically on introverted sensing and introverted intuition.

Keywords: reader perspective; psychological type; SIFT method; psychology; Bible.

\section{Introduction}

\section{The sensing, intuition, feeling, thinking approach to biblical hermeneutics}

The sensing, intuition, feeling, thinking (SIFT) approach to biblical hermeneutics, as illustrated by Francis and Atkins (2000, 2001, 2002) and as analysed by Francis and Village (2008), is situated within the reader perspective tradition of scriptural interpretation. Whilst the pioneering studies that established the reader perspective tradition concentrated on exploring sociological categories that distinguished defined groups of readers (see eds. Segovia \& Tolbert 1995a, 1995b), the SIFT approach to biblical hermeneutics explores psychological categories, drawing specifically on the Jungian model of psychological type theory (see Jung 1971). The SIFT approach proposed that the reading and interpretation of sacred text were influenced by the readers' preferences as defined and clarified by Jung's conceptual model of the human psyche and as developed and presented by such psychometric instruments as the Myers-Briggs Type Indicator (Myers \& McCaulley 1985), the Francis Psychological Type Scales (Francis 2005; Francis, Laycock \& Brewster 2017) and the Keirsey Temperament Sorter (Keirsey \& Bates 1978).

This model of psychological type distinguishes between two core psychological processes, the perceiving process, concerned with receiving and assimilating information, and the judging process, concerned with making decisions based on information gained by the perceiving process. The original insight of psychological type theory is that each of these two processes is expressed through two opposing yet complementary functions. The perceiving process is expressed through the sensing function and through the intuitive function. The judging process is expressed through the thinking function and through the feeling function. Psychological type theory maintains that whilst individuals need to draw on all four psychological functions, in the case of each pair of functions, individuals prefer one over the other (either sensing or intuition, and either thinking or feeling). As a consequence of preferring one function over the other function, individuals tend to rely on the preferred functions and to develop those functions in their daily life, neglecting the less preferred functions. 
Translated into the field of biblical hermeneutics, Francis and Village (2008) argued that the full and rounded interpretation of sacred text benefited from engagement with all four of these psychological functions, but that preachers may be drawn naturally to read and to proclaim scripture through the lens of their preferred functions (either sensing or intuition, and either thinking or feeling). Francis and Atkins $(2000,2001,2002)$ set out to illustrate how scripture might be read when all four functions were brought to bear, employing the two perceiving functions first, in the order of sensing (S) followed by intuition (I), and the two judging functions next, in the order of feeling $(\mathrm{F})$ followed by thinking $(\mathrm{T})$, hence the acronym (SIFT). Because the present study has been designed to concentrate on the perceiving functions, the rest of this introduction will not consider the judging functions.

\section{Two perceiving functions}

Psychological type theory, as developed and presented by psychometric instruments, tends to distinguish between preference for sensing and preference for intuition in the following way. Sensing types display a preference for the real, for the tangible, for the concrete and for the present. Intuitive types display a preference for the 'big picture', the patterns linking data and the possibilities latent for the future embedded in such links. Characteristics associated with a preference for sensing include being oriented to present realities, being factual and concrete, focusing on what is real and actual, observing and remembering details, building thoughtfully and carefully towards conclusions, understanding ideas and theories through practical applications, and trusting experience. Characteristics associated with a preference for intuition include being oriented to future possibilities, being imaginative and verbally creative, focusing on patterns and meanings in data, remembering details when they relate to a pattern, moving quickly to conclusions, following hunches, wanting to clarify ideas and theories before putting them into practice, and trusting inspiration.

Translating these two perceiving functions into the context of biblical hermeneutics and liturgical preaching, Francis and Village (2008) suggested that individuals who prefer sensing have a keen interest in the text that is there in front of them. When they confront the passage of scripture on which they intend to preach, their first response is to savour the details in the text, to find out all they can about that text and to get to know well what the text is saying. This may mean crossreferencing the passage with other parts of the Bible, looking at what the commentaries have to say about the meanings of the words and setting the passage in its proper historical and cultural context. Preachers who prefer sensing will want to share this basic and fundamental research with their listeners.

On the other hand, individuals who prefer intuition have the ability to penetrate the mass of detail to discern clear patterns or emerging themes. When intuitive types confront the passage of scripture on which they intend to preach, their first response is to unravel distinctive patterns within the narrative and to identify big themes or major issues behind such distinctive aspects. Rather than concentrating on the details of the passage itself, preachers who prefer intuition will begin to link the emerging themes with other sources of inspiration to develop those themes further. This may mean linking the passage with very diverse parts of scripture, with ideas running through literature, or with current themes illustrated by television, films or other sources of inspiration. For intuitive types, the big themes are so much more important than the minutiae of the text.

It is important to recognise how the distinctive characteristics of sensing and intuition bring both strengths and weaknesses to the hermeneutical process of perception. The sensing types' preference for facts and details may bring to the pulpit a wealth of information and carefully recorded evidence about the text of scripture and about the contemporary world. Sensing types may, however, have failed to grasp and to identify the major themes and bigger pictures to which the text points. The intuitive types' preferences for seeing links and possibilities may bring to the pulpit a well-developed reflection for which the text of scripture was the essential springboard. Yet, by the time the sermon is preached, the text itself may have been well and truly submerged, if not totally forgotten. Intuitive types may lose touch with the evidence, being so caught up in the interpretation.

Whilst Francis and Village (2008) offered these insights regarding biblical hermeneutics and liturgical preaching on the basis of extrapolation from the principles of psychological type theory, a subsequent series of empirical studies have tested and generally supported these conclusions. These empirical studies have invited individuals to work together in type-alike groups, forming distinctive hermeneutical communities. In terms of the perceiving process, generally, three groups have been formed, comprising individuals who are aware of a clear preference for sensing, individuals who are aware of a clear preference for intuition and individuals who are not aware of a clear preference for either sensing or intuition. The research interest is then placed on the two contrasting groups with clear preferences either for sensing or for intuition. These type-alike groups demonstrate that the sensing preference emerges strongly when sensing types are neither distracted nor challenged by intuitive types and that the intuitive preference emerges strongly when intuitive types are neither distracted nor challenged by sensing types.

Currently workshops of this nature have explored the following passages of scripture, initially focusing on the four Gospels: the feeding of the 5000 reported in Mark 6:34-44 (Francis 2010); the resurrection narratives reported in Mark 16:1-8 and Matthew 28:1-15 (Francis \& Jones 2011); the cleansing of the Temple and the incident of the fig tree reported in Mark 11:11-21 (Francis 2012a; Francis \& ap Siôn 2016b); the Johannine feeding narrative reported in John 6:4-22 (Francis 2012b); the narrative of separating sheep from goats reported in Matthew 25:31-46 (Francis \& Smith 2012); the birth narratives reported in Matthew 2:13-20 and Luke 2:8-16 (Francis \& Smith 2013); two narratives concerning 
John the Baptist reported in Mark 1:2-8 and Luke 3:2b-20 (Francis 2013; Francis \& Smith 2014); the Johannine feeding narrative reported in John 6:5-15 (Francis \& Jones 2014); two passages from Mark exploring different aspects of discipleship reported in Mark 6:7-14 and Mark 6:33-41 (Francis \& Jones 2015a); the foot washing account reported in John 13:2b-15 (Francis 2015); two healing narratives reported in Mark 2:1-12 and Mark 10:46-52 (Francis \& Jones 2015b); the narrative of blind Bartimaeus reported in Mark 10:46-52 (Smith \& Francis 2016); the Road to Emmaus narrative reported in Luke 24:13-35 (Francis \& ap Siôn 2016a; Francis \& Smith 2017); the Lucan call of the first disciples reported in Luke 5:1-7 (Francis \& ap Siôn 2017); the missionary journey reported in Mark 6:6b-16 (Francis, Smith \& Francis-Dehqani 2017); the Matthean pericopes on Pilate and Judas in Matthew 27:3-10, 19-25 (Francis \& Ross 2018); the messages of grace in Matthew 6:25-30 and Matthew 20:1-15 (Francis, Smith \& Francis-Dehqani 2018); the account of the Baptism of Jesus in Mark 1:4-9 (Francis, Jones \& Martinson 2019); the search for the lost sheep in Matthew 18:10-14 (Jones \& Francis 2019) and the teaching about binding and loosing on earth in Matthew 18:15-18 (Francis, Jones \& Hebden 2019). More recently, this research tradition has also been applied to the Suffering Servant passages from Isaiah 49 and 50 (Francis 2017) and to the Psalms: Psalm 1 (Francis, McKenna \& Sahin 2018; Francis \& Smith 2018), Psalm 139 (Francis, Smith \& Corio 2018) and Psalm 73 (Francis, Jones \& Ross 2020; Francis, McKenna \& Sahin 2020).

\section{Developing the sensing, intuition, feeling, thinking approach}

Psychological type theory is both richer and more complex than simply distinguishing amongst the four functions of sensing, intuition, feeling and thinking. Jung's theory of psychological type not only distinguishes amongst the four functions but also distinguishes between the two orientations within which each function can be expressed. On this account, the perceiving process distinguishes amongst four functions: extraverted sensing, introverted sensing, extraverted intuition and introverted intuition. The judging process also distinguishes amongst four functions: extraverted feeling, introverted feeling, extraverted thinking and introverted thinking. This approach to psychological type theory that differentiates amongst the eight function orientations (rather than simply amongst the four functions) has been discussed by Beebe (1992, 2017), Thompson (1996), Berens (1999), Haas, McAlpine and Hurtzler (2001), Hartzler and Hartzler (2004, 2005), Berens and Nardi (2004), Hartzler, McAlpin and Haas (2005), Haas and Hunziker (2006) and Ross and Francis (2020).

In their general introduction to the engagement of the sensing function within the SIFT approach, Francis and Ross (2018) argue that sensing types focus on the given evidence of the present situation as perceived by the senses. Sensing types tend to be concerned with specific details, rather than the overall picture. They are concerned with the actual, the real and the practical, tending to be down to earth and matter of fact. In differentiating between extraverted sensing and introverted sensing, Hartzler, McAlpine and Haas (2005:2) argue that for extraverted sensing types, 'the focus is on information being acquired in the moment'; extraverted sensing has an outward orientation. For introverted sensing types, where introverted sensing has an inward orientation, 'the focus is on information recalled from previous experience'.

In their general introduction to the engagement of the intuitive function within the SIFT approach, Francis and Ross (2018) argue that intuitive types focus on the possibilities of the situation, perceiving meanings and relationships. They tend to concentrate on associations, intuitions and the wider themes that go beyond the sense perceptions. Intuitive types tend to focus on the bigger picture and on the future possibilities, rather than on specific facts and details. In differentiating between extraverted intuition and introverted intuition, Hartzler et al. (2005:3) argue that for extraverted intuitive types, 'the focus is on recognising patterns and identifying possibilities for new patterns and methods of associating the information', in the external world, for extraverted intuition has an outward orientation. For introverted intuitive types, 'the focus is on synthesising information, identifying the deeper and ultimate meaning as symbolism represented by the information'. Introverted intuition has an inward orientation.

In an initial attempt to test the contribution that could be made to hermeneutical theory by structuring hermeneutical communities on the basis of the participants' preferred function orientations, Francis, Strathie and Ross (2019) reported on reading the Beatitudes (Mt 5:1-10) through the lenses of introverted intuition and introverted sensing. This initial analysis confirmed the potential within such an approach.

\section{Research question}

Against this background, the aim of the present study was to invite individuals who were well versed in psychological type theory to function as hermeneutical communities working in small groups organised on the basis of their preferred perceiving function orientation, positioned either in the dominant or the auxiliary location. The passage of scripture on which they were invited to focus was the Johannine narrative of the Wedding at Cana. It was hypothesised that this passage was rich in material engaging the perceiving process and that clear contrasts would emerge between the ways in which the different perceiving function orientations would deal with this material.

\section{Method \\ Procedure}

In the context of a residential meeting convened by the Network for Psychological Type and Christian Faith, participants were given the opportunity to take part in a workshop designed to provide an experience of exploring scripture in groups organised on the basis of their preferred 
perceiving function orientation. Before dividing into groups, John 2:1-11 was read aloud from the New Revised Standard Version (Anglicised Edition). Printed copies of the passage were provided for each participant, with the instruction 'Bring your preferred perceiving function-orientation out to play: what do you notice in this passage of scripture?'.

\section{Participants}

The workshop was attended by 17 participants, 11 men and six women: eight participants identified as preferring extraverted intuition (six men and two women); seven participants identified as preferring introverted intuition (four men and three women); two participants identified as preferring introverted sensing (one man and one woman) and no participant identified as preferring extraverted sensing. This distribution reflects the invisibility of extraverted sensing within religious communities (Ross 2011).

\section{Analysis}

In accordance with their own type preference, two of the authors took responsibility for noting the discussion that took place within their group (introverted sensing and introverted intuition), paying attention to both the process and the content. The results section is based on an analysis of these records of the discussion.

\section{Results \\ Introverted sensing}

The small group of two introverted sensing types (both extraverts) set to the task quickly and in a focused way that was aided by a conversational style drawing upon their preference for extraversion. The task itself, asking what do you notice in the passage of scripture, was not discussed, but could be seen as a task that is naturally sensing. The two members of the group began by noticing the detail they saw within the passage, pointing to the precise descriptive details that John uses; for example, the third day, and the six stone jars. Secondly, the structure and sound of the passage were noted, its short staccato sentences, these resonated with experiences of music and of choral singing in particular.

The group was then drawn to the figure of Jesus, mapping out not only the details of the story itself but also its place within the wider context of his ministry. It was clear from John's account that this story is at the beginning of Jesus' public ministry. This led to the belief that Jesus was the key character within the story. The group mused on the precise nature of the invitation to the wedding, noticing the relationship dynamics mentioned in the text that his mother, Mary, was present, along with the disciples (though no actual number is given in the pericope). Looking at the relationships immediately led to a narrower focus on the words shared between Mary and Jesus, 'Woman, what concern is that to you and to me? My time has not yet come'. Both participants had a strong reaction to these words in the New Revised Standard Version. For one, it was an embodied uneasiness, but for the other, it evoked a vivid recalling of the Greek New Testament class in which the cultural and linguistic context had been first discussed. This participant could still hear the tutor's voice speak out loud those words. He could recall and feel the intonation given to the words, now some many years ago.

The group then went on to consider the actions of the miracle itself. These actions appear to have a certain order to them, a progression of stages; the wine was first taken out of the stone jar, the wine was then passed to the chief steward and then the wine was tasted. Other miracles in John's Gospel were noticed for having similar action patterns within them, for example, the Man Born Blind in John chapter 9. In that miracle, first Jesus spits on the ground, then Jesus makes mud, then Jesus places the mud on the man's eyes and then the man goes to wash.

The next thing to stimulate discussion was a realisation that this miracle is only recorded in John's Gospel. But in John's Gospel, it is the first miracle to be recorded, and is it therefore the first time that Jesus' glory was revealed? How did this miracle affect the way in which the disciples saw Jesus as teacher/Rabbi? How did this miracle affect the way in which they now saw Jesus as someone with power and authority?

With a return to the text to focus on the next part of the story, attention was directed to the wine itself. How different was the wine? How different did it need to be for people to notice that much difference, even when they were drunk? The lack of any comments from the stewards is noted. Although they knew where the wine had come from, they do not say where it had come from. Is this because Jesus asked them not to, as we see elsewhere in John's Gospel? The group shared in a joke and laughed together, that if he had done, he could have had a wedding invitation every week.

\section{Introverted intuition}

The conversation between the seven introverted intuitive types (five introverts and two extraverts) started slowly as individuals explored their own rich resource of introverted connections. The opening phrase of the narrative, 'On the third day' provided a stimulus for making connections and seeking deeper meaning. Symbolically, the third day pointed to the day of the resurrection. These introverted intuitive types wanted to explore and connect with the symbolic significance of the two preceding days. On day one, John the Baptist had pointed to Jesus as the Lamb of God, and on day two, there was Jesus' encounter with Nathaniel. It was clear that the idea of the third day was very rich.

The end of the first sentence offered a second springboard for making connections with its words 'and the mother of Jesus was there'. One participant asked, 'Now why did John lead with reference to the mother of Jesus, rather than with reference to Jesus?' In quick succession, there followed other queries: 'What was so special about this woman at that wedding?'; 'And the prominence given to a woman within a 
patriarchal society is itself puzzling'. Participants were striving to make multiple connections.

A variety of statements then tumbled forth: the reference to the idea that 'Jesus and his disciples had been invited to the wedding' added prominence to Mary as the priority guest. One of the participants suggested that Jesus was there as a consequence of Mary's invitation to be there. Then, another participant made a connection with 'tradition' that says that the wedding was for a member of Mary's family. Then another surmise was that Jesus is himself the bridegroom at the Messianic banquet. The idea that Jesus was the bridegroom could also explain why Jesus' disciples were there. But we do not know how many of his disciples were involved. This Gospel's author is silent about that.

The next most puzzling question concerns why Mary pointed out to Jesus the problem caused by the wine running out. What did she expect him to do? And why did she give the enigmatic instruction to the servants, 'Do whatever he tells you'. What power did she have over the servants? And what shaped her view that Jesus could fix things like this? Here is the picture of Mary as the driving force and of Jesus responding to her initiative. One participant made a connection to the God who responds to the individual. Another participant made a connection to Mary Magdalen to whose need elsewhere in the Gospels Jesus is recorded as responding.

The six stone water-jars were also a source of puzzlement. Each one held 20 or 30 gallons. Were they really so big? Can you imagine how tall they were and how the servants managed to fill them? Or, perhaps they were already far from empty and all the servants had to do was to top them up. And what can you do with so much wine, between 120 and 180 gallons of it? The fact that John speaks of six jars was also a matter of interest. The connection was made that six is one short of seven, the perfect number. When reading John's Gospel, we must always be looking for symbolism in order to get to the deeper meaning.

The sheer quantity of wine deserved closer scrutiny. Why did Jesus make so much wine? What would the recovering alcoholic in the congregation, hearing this reading, then make of it? Is Jesus not making the path to sobriety more difficult? How would the argument work that wine made so quickly would not have had time to ferment properly, and so be low in alcohol or even be nonalcoholic? But that argument did not really satisfy anyone.

The next idea to catch attention was the chief steward's reference, 'after the guests have become drunk'. Connecting to other translations prompted different interpretations and different meaning: some translations say 'had their fill'. Connecting to images of festivals of long duration prompted the thought that at such festivals, people drink slowly over time. But beyond this, the behaviour of the chief steward was puzzling. The servants knew where the wine had come from, so why did not the chief steward?
It was, however, the last sentence from the selected passage (verse 11) that generated the longest discussion amongst this group of introverted intuitive types. So what is the symbolism of this, the first of the signs? Does the turning of water into wine prefigure a renewed creation? What are the other signs reported in John's Gospel, and how do all these signs fit together? This first sign revealed Jesus' glory and his disciples believed in him. Connections were then made with the end of John's Gospel that says that, if all the signs that Jesus did were written down, the whole world would not hold the books, but what had been written was written that you may believe and that believing you may have eternal life.

\section{Discussion}

This study has set out to employ the SIFT approach to biblical hermeneutics in order to investigate the interpretation of the account of the wedding at Cana through the lens of participants for whom a leading function-orientation, whether as dominant or auxiliary, was introverted sensing, and those for whom a leading function-orientation was introverted intuition. In the presentation of results, distinctive voices seem to arise from the deployment of both of these function-orientations. The purpose of this section is to discuss these findings in relation to (1) established formulations and emerging issues in psychological type theory, and in dialogue with (2) previous research from the empirical inquiry into the SIFT approach to sacred texts thus far in the Hebrew Bible Psalms 1 and 73 - and numerous New Testament studies, with a view to (3) confirming and extending the construct validity of function-orientations first formulated by Jung (1971) and refined by Beebe (2016), Thompson (1996) and Ross and Francis (2020).

\section{Introverted sensing}

The discussion between participants of this group illustrates several features of introverted sensing that characterise the operation of sensing when it is inwardly directed, and which are found both in Jung's original formulations (Jung 1971) and those in the subsequent, empirical secondary literature (Myers \& McCaulley 1985). These include (1) an orientation to precise detail, (2) a concern for specifics in the present that are familiar and which trigger eidetic re-experiencing of past experiences and (3) seeking out routine, procedures and sequences.

Introverted sensing is concerned with subjective resonance to external phenomena that occur in our shared world, as Ross and Francis (2020) observe:

To explain introverted sensing, Carl Jung used the example of several painters who paint the same garden but produce a different picture. For Jung, the subjective factor at the core of introverted sensing is decisive because the reactions of the perceiving subject are elevated above the properties of the object that is perceived. (p. 19)

This characteristic of the way introverted sensing operates is reflected in the present study in both members' strong 
response with regard to Jesus' seeming remonstration to his mother in which he addressed her as 'woman'. One participant is reported as being transported back to his Greek New Testament class many years earlier, hearing it afresh as it was with visceral resonance, regarding his tutor's enunciation of the Greek words both in regard to content and tone. Indeed, introverted sensing perceives the world by recalling the tangible sensory memory of previous experiences. Attention is drawn to an inner re-experiencing and there occurs a sorting through past materials in relation to the specific details of present experience. It uses how things have been before' as a reference point, serving to establish, maintain and conserve continuity between the past and the present. Working in a group of like-minded introverted sensing colleagues may enable a familiar worldview to be constructed and maintained, reinforcing one another's past experience; any testing out of ideas will be drawn from previous experience, recalled from lived moments or past learning.

In regard to a natural orientation to details and specifics, the present group wanted to clarify the exact nature and breadth of the wedding invitation offered to Jesus. Did it explicitly include both his disciples and his mother Mary? For this would afford a more precise grasp of the relational dynamics that might shed more light on Jesus' seemingly terse response to Mary's informing him of the shortage of wine: 'Woman what concern is that to you and me?' Significantly, the introverted sensing types did not speculate on Jesus' next declaration that points to the future 'My hour has not come', preferring to seek clarification of the recent past for the light it may shed on the present, rather than give themselves over to conjecture.

Furthermore, regarding the concern with specifics, the group had already started their discussion by noting John enumerating that the wedding was on Jesus' third day in Galilee, and there being six water jars with a capacity of between 20 and 30 gallons. It was noted that this was the first miracle of Jesus' ministry and that John's Gospel is the one Gospel in which it is recorded. Such details are both 'noteable' by - and noteworthy to - the function-orientation of introverted sensing: "The physical sensitivity to objects and other people takes in every shade and detail' (Sharpe 1987:79, in Ross \& Francis 2020:20). It was apparent from their selfreport too that these introverted sensing types would have wished to examine the wine itself for the degree of difference in the wine that was required for the guests to register a difference on their palate that it was in fact a different kind of wine. Group members also picked up on the fact that the servants did not tell the chief steward. This omission was not lost on either member, but again there was no speculation.

Introverted sensing seeks routine, procedure and familiarity: 'Introverted sensing enables us to recall the exact sequence of events as they occurred' (Ross \& Francis 2020:20). In keeping with this quality, the group commented on the miracle itself as having a distinct order: a progression of stages where the wine was taken from its container, then tasted and then passed to the steward. The members were reminded of a similar action sequence - of Jesus' healing the man born blind in the same Gospel: Jesus spitting on the ground, making mud, mud being placed on the blind man's eyes, washing instructions provided to him and then followed.

Discussion amongst the introverted sensing types did not build on from the text of John's Gospel to make connections to the world but remained firmly focused on commenting on the actual text. Associations to other parts of John's Gospel were identified and mentioned, and consistencies were seen and appreciated. They shared their own experiences connected with the Gospel through memories that were evoked by the text.

\section{Introverted intuition}

The discussion amongst the seven participants for whom the function-orientation of introverted intuition was a leading part of their personality, the 'heroic' dominant for five of them and the nurturing 'auxiliary' (Ross \& Francis 2020) for the other two members illustrates several features of introverted intuition that characterise the operation of intuition when it is inwardly directed, as found in Jung's original formulations (Jung 1971) and those in the subsequent, empirical secondary literature (Myers \& McCaulley 1985). These features are as follows - listed here in the paragraphic order in which they are initially reported in the Results section: (1) vigilance for and concern with the symbolic, (2) the 'normal' struggle for and towards meaning, (3) comfort with complexity, (4) taking satisfaction in the dynamics of diversity as part of the process of the hermeneutics of interpretation and (5) contentment with discussion and texts remained open-ended. Furthermore, (6) the products of intuitive inquiry - whether issuing as questions or as statements - have intrinsic value -requiring no external evidence and finally (7) connections are made on the basis of intuitively perceived patterns of meaning, in contrast to introverted sensing that is triggered by details to make specific associations.

Vigilance for and concern with the symbolic, and comfort with complexity: Ross and Francis (2020) note regarding introverted intuitive dominants that 'Fascination with their own complex imagination may draw some ... to the systems of symbols found in the myths and rituals of religions' (p. 92). By the same token, the Christian introverted intuitive types in the current study started their discussion by pointing to the poignancy of John remarking that the miracle at the Cana wedding occurred at the start of Jesus' ministry and on the third day in Galilee when 'the third day' is the customary term used to introduce the event of the Resurrection of Jesus at the very end of John's Gospel. Here - at least to these two introverted intuitive authors of the current journal article - the idea of the hologram 'comes to mind', wherein the structure of a 'part' that goes into comprising part of a 'whole' also mimics the structure of the wider whole of which it is a part. In a similar way, at the 
very end of their group time, the introverted intuitive participants conclude their discussion by pondering how the wine miracle may have been selected by the author of John's Gospel, who has been claimed as an intuitive type by previous scholars of type and exegesis (King 2015), as the first of the seven signs in that Gospel. They reflected that this particular sign prefigures the transformation of creation in the tangible form of Jesus' resurrection that occurs at the end of John's Gospel.

In the conversation within this group, connections were frequently made on the basis of intuitively perceived patterns of meaning. For introverted intuitive types, the struggle for and towards meaning is normal both in the midst of everyday life and especially poignant times in life. Such struggle is not necessarily associated with angst as it may be for the sensing majority that prevails in most cultural and institutional settings in European and Asian-based societies (Myers et al. 2018). Indeed, for strong introverted intuitive types, the puzzle and struggle with a meaning and meanings are usually stimulating and enlivening, as may be sensed from the report of their discussion in this study:

Jesus was clearly there as a consequence of Mary's invitation to be there. Then, a connection was made with 'tradition' that says that the wedding was for a member of Mary's family. Then, another surmise was that Jesus is himself the bridegroom at the Messianic banquet. That may explain, too, why Jesus' disciples were there.

Jung has explained such energetic connecting: '[I]ntroverted intuition resonates to inner images laid down in what he called the collective unconscious' which are 'mediated by archetypes that represent the distillation of intense experiences repeated since time immemorial' and so these inner images 'are produced in such inexhaustible abundance by the creative energy of life', they come to 'represent possible views of the world which may give life a new potential' (Ross \& Francis 2020:24; quoting Jung 1971:400).

Furthermore, Haas and Hunziker (2006) in their thoroughgoing definition identify introverted intuition as oriented to 'discover underlying significance, systems and meaning' (p. 63). Therefore, when intuition is cast in a reflective inward direction, contrasting and even contradictory interpretations as well as complementary ones naturally emerge and are accepted. This was a consistent feature of the conversation in the introverted intuitive group as it traversed the variety of happenings, encounters and dialogues at the wedding feast that the evangelist presents to the reader. The discussants appeared to enjoy their hermeneutic diversity. They also seemed satisfied and comfortable to leave the meeting with more questions asked than answers provided. Both text and discussion finished in an open-ended way and that was fine. Introverted intuition has an immense span:

$[I] \mathrm{t}$ affords us the specie aeternitatis of Spinoza, the perspective of eternity ... [Introverted intuition] in its extraordinary aspect enables prophecy, and in its everyday form, provides an inner vision that transcends the present moment and sets trials and tribulations in a wider context. (Ross \& Francis 2020:24)
As such, products of introverted intuitive inquiry - whether issuing as questions or statements - carry intrinsic value: 'introverted intuition comes with great conviction of its own truth' (Ross \& Francis 2020:24). Hence, no external supporting evidence is required. It was evident that the members of this group were not restrained in their remarks by an obligation to provide reasoning or evidence.

Introverted intuition perceives the world by shaping connections, and by identifying patterns and deep meaning beneath the surface of things. Hunches, insights and knowing arrive suddenly mediated by embedded symbols and metaphors. Participants within a group of introverted intuitive types are employing intuition inwardly. Each one is more concerned with what is happening within his or her inner life than with what is happening in the external world of the group. Whilst working in a group of like-minded colleagues may help to affirm and stimulate the generation of new ideas and new connections, the group itself can also serve as an unnecessary distraction to the inner exploration.

Discussion amongst the introverted intuitive types needed the text of John's Gospel to get the conversation started, but then the introverted intuitive types quickly reached out to make new connections. The sense remained throughout that each of the seven participants was more absorbed with the connections being formed in his or her own mind than with trying to grasp what was going on in the minds of others.

\section{Conclusion}

The present study built on and developed the insights afforded by the SIFT approach to biblical hermeneutics and liturgical preaching, as proposed by Francis and Village (2008) and as tested in the series of empirical studies identified in the introductory section of the article. The SIFT approach is concerned with identifying the distinctive perspectives that characterise the readings of scripture voiced by sensing and intuition (the two perceiving functions) and by thinking and feeling (the two judging functions) as proposed by Jungian psychological type theory (Jung 1971).

The present study has recognised that psychological type theory is both richer and more complex than simply distinguishing amongst the four functions of sensing, intuition, feeling and thinking. Jung's theory also distinguishes between the two orientations within which each function can be expressed. The eight function-orientation model of psychological type theory, therefore, distinguishes between the introverted expression and the extraverted expression of each of the four functions. This approach has been discussed and conceptualised by Beebe (1992, 2017), Thompson (1996), Berens (1999), Haas, McAlpine and Hurtzler (2001), Hartzler and Hartzler (2004, 2005), Berens and Nardi (2004), Hartzler et al. (2005), Haas and Hunziker (2006) and Ross and Francis (2020).

In an initial study, Francis et al. (2019) tested the contribution that could be made to hermeneutical theory by structuring hermeneutical communities on the basis of the participants' 
preferred function orientations. In that study, they reported on reading the Beatitudes (Mt 5:1-10) through the lenses of introverted intuition and introverted sensing. Their initial analysis confirmed the potential within such an approach. Building on that initial study, the present study has focused on the same two function-orientations (introverted sensing and introverted intuition) and applied them to a second (and very different) passage of scripture: the Wedding at Cana in Galilee (Jn 2:1-11). This second study has also confirmed the potential within such an approach.

The main conclusion drawn from these two studies considered together is that the specific focus on the introverted form of sensing and the introverted form of intuition provided an interesting contrast that highlighted distinctive qualities of engagement with biblical text and enriched the depth of resonance that the SIFT method of biblical hermeneutics brings to this reader-perspective approach to the interpretation of scripture. The study is clearly limited by its focus on just two of the eight function orientations, on only two passages of scripture and on only two groups of participants. These are limitations that can be addressed by further research shaped within the same tradition. Such exploration is particularly pertinent amongst groups of participants who are well versed in psychological type theory and well familiar with Christian scriptures.

\section{Acknowledgements Competing interests}

The authors declare that they have no financial or personal relationships that may have inappropriately influenced them in writing this article.

\section{Authors' contributions}

L.J.F. took responsibility for overall conceptualisation of the article. L.J.F. and A.J.S. served as observers in the group; C.F.J.R. organised the discussion. All three authors analysed the data, and shaped the article.

\section{Ethical considerations}

Ethical approval to conduct the study was obtained from the School Research Ethics Committee, York St John University (reference no. HRP-RS-AV-12-20-01).

\section{Funding information}

This research received no specific grant from any funding agency in the public, commercial or not-for-profit sectors.

\section{Data availability}

Data are available from the first author (L.J.F.).

\section{Disclaimer}

The views and opinions expressed in this article are those of the authors and do not necessarily reflect the official policy or position of any affiliated agency of the authors.

\section{References}

Beebe, J., 1992, Integrity in depth, Texas A \& M University Press, College Station, TX.

Beebe, J., 2016, Energies and patterns in psychological type: The reservoir of consciousness, Routledge, London.

Beebe, J., 2017, Energies and patterns in psychological type: The reservoir of consciousness, Routledge, Abingdon.

Berens, L., 1999, Dynamics of personality type: Understanding and applying Jung's cognitive processes, Telos Publications, Huntington Beach, CA.

Berens, L.V. \& Nardi, D., 2004, Understanding yourself and others: An introduction to the personality type code, Telos Publications, Huntington Beach, CA.

Francis, L.J., 2005, Faith and psychology: Personality, religion and the individual, Darton, Longman and Todd, London.

Francis, L.J., 2010, 'Five loaves and two fishes: An empirical study in psychological type and biblical hermeneutics among Anglican preachers', HTS Theological Studies 66(1), article 811, 1-5. https://doi.org/10.4102/hts.v66i1.811

Francis, L.J., 2012a, 'What happened to the fig tree? An empirical study in psychological type and biblical hermeneutics', Mental Health, Religion and Culture 15(9), 873-891. https://doi.org/10.1080/13674676.2012.676252

Francis, L.J., 2012b, 'Interpreting and responding to the Johannine feeding narrative: An empirical study in the SIFT hermeneutical method among Anglican ministry training candidates', HTS Theological Studies 68(1), article 1205, 1-9. https://doi. org/10.4102/hts.v68i1.1205

Francis, L.J., 2013, 'Ordinary readers and reader perspective on sacred texts: Drawing on empirical theology and Jungian psychology', in J. Astley \& L.J. Francis (eds.), Exploring ordinary theology: Dimensions of everyday Christian existence and the life of the Church, pp. 87-96, Farnham, Ashgate.

Francis, L.J., 2015, 'Footwashing and diaconal ordination', in J. Vincent (ed.), The farewell discourses in practice, pp. 21-28, Deo Publishing, Blandford Forum.

Francis, L.J., 2017, 'The servant and psychological types', in J.W. Rogerson \& J. Vincent (eds.), The servant of God in practice, pp. 92-104, Deo Publishing, Blandford Forum.

Francis, L.J. \& ap Siôn, T., 2016a, 'Jesus, psychological type and conflict: A study in biblical hermeneutics applying the reader perspective and SIFT approach to Mark 11: 11-21', HTS Theological Studies 72(4), article 3573, 1-9. https://doi. org $/ 10.4102 /$ hts.v72i4.3573

Francis, L.J. \& ap Siôn, T., 2016b, 'Empirical theology and biblical hermeneutics: Exploring lessons for discipleship from the Road to Emmaus (Luke 24: 13-35)' Journal of Empirical Theology 29(1), 24-44. https://doi.org/10.1163/1570925612341000

Francis, L.J. \& ap Siôn, T., 2017, 'Reading the Lucan call of the first disciples differently: The voices of sensing and intuition', Journal of Beliefs and Values 38(2), 188-198. https://doi.org/10.1080/13617672.2017.1291254

Francis, L.J. \& Atkins, P., 2000, Exploring Luke's Gospel: A guide to the gospel readings in the Revised Common Lectionary, Mowbray, London.

Francis, L.J. \& Atkins, P., 2001, Exploring Matthew's Gospel: A guide to the gospel readings in the Revised Common Lectionary, Mowbray, London.

Francis, L.J. \& Atkins, P., 2002, Exploring Mark's Gospel: An aid for readers and preachers using year B of the Revised Common Lectionary, Continuum, London.

Francis, L.J. \& Jones, S.H., 2011, 'Reading and proclaiming the resurrection: An empirical study in psychological type theory among trainee and experienced preachers employing Mark 16 and Matthew 28', Journal of Empirical Theology 24(1), 1-18. https://doi.org/10.1163/157092511X571141

Francis, L.J. \& Jones, S.H., 2014, 'Life in the eucharistic community: An empirical study in psychological type theory and biblical hermeneutics reading John 6: 5-15', Pastoral Psychology 63(3), 281-290. https://doi.org/10.1007/s11089-013-0540-x

Francis, L.J. \& Jones, S.H., 2015a, 'An empirical approach to Mark's account of discipleship: Conversation between the Word of God and the People of God', Rural Theology 13(1), 69-81. https://doi.org/10.1179/1470499415Z.00000000042

Francis, L.J. \& Jones, S.H., 2015b, 'Preparing for Disability Awareness Sunday: An educational exercise drawing on psychological perspectives for biblical hermeneutics', International Journal of Christianity and Education 19(3), 197-214. https://doi.org/10.1177/2056997115602485

Francis, L.J., Jones, S.H. \& Hebden, K., 2019, 'Binding and loosing on earth: Evaluating the strategy for church disciplinary procedures proposed in Matthew 18: 15-18 through the lenses of thinking and feeling, HTS Theological Studies 75(3), article 5474, 1-10. https://doi.org/10.4102/hts.v75i3.5476

Francis, L.J., Jones, S.H. \& Martinson, J., 2019, 'Exploring the Marcan account of the Baptism of Jesus through psychological lenses: An empirical study within a Blackled Black-majority Pentecostal church', Journal of the European Pentecostal Theology Association 39(1), 100-115. https://doi.org/10.1080/18124461.2019.1 592330

Francis, L.J., Jones, S.H. \& Ross, C.F., 2020, 'Is God really good to the upright? Theological educators exploring Psalm 73 through the Jungian lenses of sensing intuition, feeling and thinking', HTS Theological Studies 76(1), article 6171, 1-10. https://doi.org/10.4102/hts.v76i3.6093

Francis, L.J., Laycock, P. \& Brewster, C., 2017, 'Exploring the factor structure of the Francis Psychological Type Scales (FPTS) among a sample of Anglican clergy in England', Mental Health, Religion and Culture 20(9), 930-941. https://doi.org/10. 1080/13674676.2017.1375469

Francis, L.J., McKenna, U. \& Sahin, A., 2018, 'Facing the issues raised in Psalm 1 through thinking and feeling: Applying the SIFT approach to biblical hermeneutics among Muslim educators', Religions 9(323), 1-11. https://doi.org/10.3390/ rel9100323 
Francis, L.J., McKenna, U. \& Sahin, A., 2020, 'Exploring Psalm 73: 1-10 through sensing and intuition: Applying the SIFT approach to biblical hermeneutics among Muslim educators', HTS Theological Studies 76(3), article 6093, 1-7. https://doi.org/ educators', HTS Theologicd
$10.4102 /$ hts.v76i3.6093

Francis, L.J. \& Ross, C.F., 2018, 'Psychologically-informed engagement with the Matthean pericopes on Pilate and Judas through Jungian lenses: The SIFT approach',
HTS Theological Studies 74(1), article 5179, 1-12. https://doi.org/10.4102/hts. HTS Theologic
v74i.5179

Francis, L.J. \& Smith, G., 2012, 'Separating sheep from goats: Using psychological type theory in a preaching workshop on Matthew 25: 31-46', Journal of Adult Theological Education 9(2), 175-191. https://doi.org/10.1179/ate.9.2.gw21522035374468

Francis, L.J. \& Smith, G., 2013, 'Reading and proclaiming the Birth Narratives from Luke and Matthew: A study in empirical theology among curates and their training incumbents employing the SIFT method', HTS Theological Studies 69(1), article 2001, 1-13. https://doi.org/10.4102/hts.v69i1.2001

Francis, L.J. \& Smith, G., 2014, 'Reading and proclaiming the Advent call of John the Baptist: An empirical enquiry employing the SIFT method', HTS Theological Studies 70(1), article 2718, 1-9. https://doi.org/10.4102/hts.v70i1.2718

Francis, L.J. \& Smith, G., 2017, 'Learning relationships: Church of England curates and training incumbents applying the SIFT approach to the Road to Emmaus', HTS Theological Studies 73(4), Article 4546, 1-11. https://doi.org/10.4102/hts. v73i4.4546

Francis, L.J. \& Smith, G., 2018, 'Difficult texts: Psalm 1', Theology 121(3), 197-200. https://doi.org/10.1177/0040571X17749149

Francis, L.J., Smith, G. \& Corio, A.S., 2018, 'I hate them with perfect hatred: Exploring Psalm 139 through the Jungian lenses of sensing, intuition, feeling, and thinking', HTS Theological Studies 74(1), article 5058, 1-9. https://doi.org/10.4102/hts v74i1.5058

Francis, L.J., Smith, G. \& Francis-Dehqani, G., 2017, 'The missionary journey of Mark 6 and the experience of ministry in today's world: An empirical study in biblical hermeneutics among Anglican clergy', HTS Theological Studies 73(3), article 4560, 1-7. https://doi.org/10.4102/hts.v73i3.4560

Francis, L.J., Smith, G. \& Francis-Dehqani, G., 2018, 'Empirical explorations into biblical theologies of grace: Employing the SIFT approach among Anglican clergy', Journal of Psychology and Christianity 37(3), 217-234.

Francis, L.J., Strathie, D. \& Ross, C.F., 2019, 'Reading the Beatitudes (Matthew 5: 1-10) through the lenses of introverted intuition and introverted sensing: Perceiving text differently', HTS Theological Studies 75(4), article a5475, 1-8. https://doi. org/10.4102/hts.v75i4.5475

Francis, L.J. \& Village, A., 2008, Preaching with all our souls, Continuum, London.
Haas, L. \& Hunziker, M., 2006, Building blocks of personality type: A guide to using the eight process model of personality, Telos Publications, Huntingdon Beach, CA.

Haas, L., McAlpine, R. \& Hartzler, M., 2001, Journey of understanding: MBTI interpretation using the eight Jungian functions, CPP Inc., Mountain View, CA.

Hartzler, G. \& Hartzler, M., 2004, Function skill development indicator and feedback report, Type Makes a Difference, Inc., Palmetto, FL.

Hartzler, M. \& Hartzler, G., 2005, Functions of type: Activities to develop the eight Jungian functions, Telos Publications, Huntington Beach, CA.

Hartzler, M.T., McAlpine, R.W. \& Haas, L., 2005, Introduction to type and the eight Jungian functions, CPP Inc., Mountain View, CA.

Jones, S.J. \& Francis, L.J., 2019, 'Searching for the lost sheep (Matthew 18: 10-14): Do sensing types and intuitive types find different things?', Rural Theology 17(2), 106-113. https://doi.org/10.1080/14704994.2019.1585112

Jung, C.G., 1971, Psychological types: The collected works, volume 6, Routledge and Kegan Paul, London.

Keirsey, D. \& Bates, M., 1978, Please understand me, Prometheus Nemesis., Del Mar, CA.

King, D.E.N., 2015, 'The personality of the Fourth Evangelist', Mental Health, Religion and Culture 18(9), 703-711. https://doi.org/10.1080/13674676.2014.961251

Myers, I.B. \& McCaulley, M.H., 1985, Manual: A guide to the development and use of the Myers-Briggs Type Indicator, Consulting Psychologists Press, Palo Alto, CA.

Myers, I.B., McCaulley, M.H., Quenk, N.L. \& Hammer, A.L., 2018, MBTI ${ }^{\circledR}$ manual for the Global Step I and Step II assessments, 4th edn., The Myers-Briggs Company, Sunnyvale, CA.

Ross, C.F.J., 2011, 'Jungian typology and religion: A perspective from North America', Research in the Social Scientific Study of Religion 22, 166-191. https://doi. org/10.1163/ej.9789004207271.i-360.30

Ross, C.F.J. \& Francis, L.J., 2020, Personality, religion, and leadership: The spiritual dimensions of psychological type theory, Lexington Books, New York, NY.

Segovia, F.F. \& Tolbert, M.A. (eds.), 1995a, Reading from this Place: Social location and biblical interpretation in the United States, Fortress Press, Minneapolis, MN.

Segovia, F.F. \& Tolbert, M.A. (eds.), 1995b, Readings from this Place: Social location and biblical interpretation in global perspective, Fortress Press, Minneapolis, MN.

Sharpe, D., 1987, Personality types: Jung's model of typology, Inner City Books, Toronto.

Smith, G. \& Francis, L.J., 2016, 'Difficult texts: Mark 10: 46-52', Theology 119(3), 200-203. https://doi.org/10.1177/0040571×15623706

Thompson, H., 1996, Jung's function-attitudes explained, Wormhole Publishing, Watkinsville, GA. 


\section{Appendix}

\section{John 2:1-11: The Wedding at Cana}

On the third day, there was a wedding in Cana of Galilee, and the mother of Jesus was there. Jesus and his disciples had also been invited to the wedding. When the wine gave out, the mother of Jesus said to him, 'They have no wine'. And Jesus said to her, 'Woman, what concern is that to you and to me? My hour has not yet come'. His mother said to the servants, 'Do whatever he tells you'. Now standing there were six stone water-jars for the Jewish rites of purification, each holding 20 or 30 gallons. Jesus said to them, 'Fill the jars with water'. And they filled them up to the brim. He said to them, 'Now draw some out, and take it to the chief steward'. So they took it. When the steward tasted the water that had become wine, and did not know where it came from (though the servants who had drawn the water knew), the steward called the bridegroom and said to him, 'Everyone serves the good wine first, and then the inferior wine after the guests have become drunk. But you have kept the good wine until now'. Jesus did this, the first of his signs, in Cana of Galilee, and revealed his glory; and his disciples believed in him.

New Revised Standard Version (Anglicised Edition) 